\title{
Cassava starch in the Brazilian food industry
}

\author{
Amido de mandioca na indústria brasileira de alimentos
}

\section{Ivo Mottin DEMIATE ${ }^{1 \star}$, Valesca KOTOVICZ ${ }^{2}$}

\begin{abstract}
Cassava starch is a valued raw material for producing many kinds of modified starches for food applications. Its physicochemical properties, as well as its availability, have made it an interesting and challenging ingredient for the food industry. In the present work, food grade modified cassava starches were purchased from producers and analyzed for selected physicochemical characteristics. Samples of sour cassava starch were included, as well as one sample of native cassava starch. Results showed that almost all modified starches were resistant to syneresis, produced pastes more stable to stirred cooking, and some of them were difficult to cook. The sour cassava starches presented high acidity and resulted in clear and unstable pastes during stirred cooking, susceptible to syneresis.
\end{abstract}

Keywords: modified starches; sour cassava starch; Manihot esculenta; thickener; gelatinization.

\section{Resumo}

O amido de mandioca é uma matéria-prima valorizada para a produção de diversos tipos de amidos modificados para serem utilizados pela indústria de alimentos. As propriedades físico-químicas e sua disponibilidade o colocam como um ingrediente interessante e desafiador para a indústria alimentícia. Neste trabalho, amidos de mandioca modificados de uso alimentício foram adquiridos ou recebidos de produtores e analisados em relação a algumas características físico-químicas. Amostras de polvilho azedo e uma de amido nativo de mandioca foram incluídas no estudo. Os resultados mostraram que quase todos os amidos modificados foram resistentes à sinérese, produziram pastas mais estáveis ao cozimento sob agitação e algumas eram de difícil cozimento. Os polvilhos azedos apresentaram elevados valores de acidez e produziram pastas claras e instáveis ao cozimento que também foram susceptíveis à sinérese.

Palavras-chave: amidos modificados; polvilho azedo; Manihot esculenta; espessante; gelatinização.

\section{Introduction}

Cassava is a tropical crop and its center of origin is believed to be the Amazon region. It was already cultivated by South American indigenous populations when the Europeans arrived and sent genetic material to other continents. Brazil was always a leading cassava grower in the world and the roots are used for human and animal nutrition, produced mainly in small farms, being very important as a staple food for some rural communities. There is a lack of reliable statistical data about cassava cultivation in Brazil due to the fact that several times it is consumed directly by the growers, as food or animal feed and there is no commercialization. In the past years, the Brazilian production has been of about 20 to 25 million tons a year, but there is little detailed information about how the roots are used.

Cassava processing in Brazil includes the production of flours (peeled roots are grated, pressed and then dried/toasted) and of starch, also known as polvilho. For starch production, peeled roots are grated and washed with water using sieves and decantation or centrifugation for starch recovery. Cassava starch is generally dried by using flash-driers (CEREDA, 2001). There are also indigenous processes, as the production of fermented and sun-dried cassava starch or sour cassava starch, known in Brazil as polvilho azedo. This fermented and sun-dried starch presents a typical flavor and is used in the production of expanded salty biscuits and also of cheese rolls (APLEVICZ; DEMIATE, 2007; CAMARGO et al., 1998; CÁRDENAS; DE BUCKLE, 1980; CEREDA, 1983ab; DEMIATE et al., 2000; MARCON; AVANCINI; AMANTE, 2007; MARCON et al., 2007; NAKAMURA; PARK, 1975; PLATA-OVIEDO; CAMARGO, 1998; WETSBY; CEREDA, 1994), products of great sensory acceptance in Brazil. In the United States, as cited by Sharp and Sharp (1994), cassava is the second most important botanical source of industrial starch, behind corn. In that country, the biggest starch producer in the world, all starch from cassava is imported.

In food application, one of the advantages of cassava starch when compared to corn starch - that represents over $75 \%$ of the world's starch market - is the absence of the undesired "cereal flavor". This makes cassava starch preferred for application in many processed foods, with particular interest in bland flavored products. Other factor that makes cassava starch a key ingredient for food industry and also for other kinds of applications is its particular physicochemical behavior when

${ }^{1}$ Programa de Pós-Graduação em Ciência e Tecnologia de Alimentos, Universidade Estadual de Ponta Grossa - UEPG, Av. Carlos Cavalcanti, 4748, CEP 84030-900, Ponta Grossa, PR, Brazil,E-mail: demiate@yahoo.com

${ }^{2}$ Engenheira de Alimentos, Programa de Pós-Graduação em Tecnologia de Alimentos, Universidade Federal do Paraná - UFPR, Curitiba, PR, Brazil

${ }^{*}$ Corresponding author 
cooked in aqueous dispersion, producing high clarity and high viscosity pastes (CHE et al., 2007), as well as presenting a low gelatinization temperature and low tendency to retrogradation when compared to cereal starches. In Brazil, cassava starch is largely preferred by the meat processing industry, being used in sausages, ham-like products and many others. The gelatinization temperature is lower and its apparent viscosity higher than that of corn starch at the same concentration, what represents an advantage for some applications. After cooking, cassava starch paste has lower tendency to retrogradation, what is often a desired property for industrial uses. Although cassava starch has several advantages when compared to corn starch, it also has limitations like being unstable to cooking and to acidity, as other native starches (TAKIZAWA et al., 2004).

Several types of chemically modified starches are very important to the global market (BHAT; KARIM, 2009; SWINKELS, 1996; WURZBURG, 1986) and these ingredients are patented and produced mainly by the developed countries. These modified starches are very valued by the food industry for the development of new products with better sensory and nutritional quality. Low calorie and low fat foods, like mayonnaise-type sauces, are good examples of modified starches applications. The main purposes of adding starch to processed foods are related to desired consistency or texture and to the increase of water retention inside the products, what results in better sensory quality as well as lower caloric value.

The main important chemically modified starches to the food industry may be grouped as the 1) cross-linked, that are produced by reaction with bi-functional reactants, also called thick boiling starches; the 2) stabilized or substituted starches made by derivatizing hydroxyl groups; and the 3) converted starches, modified by acid or oxidative treatments, generally known as thin-boiling starches. In the case of the cross-linking, starch granules become more resistant to food processing (high temperatures, high shear, low $\mathrm{pH}$ ) and present higher viscosity when cooked if compared to the native starch granules. The derivatized or substituted starches, on the other hand, were developed mainly to present stability to cold storage, which means very limited tendency to retrogradation and syneresis. Several substituted starches present good emulsifying properties with interfacial activity (BEMILLER, 2009; WURZBURG, 1986). The starches may be offered to the food market in granular form or after pre-gelatinization, what is denominated a physical modification (SCHMITZ et al., 2006).

Bemiller (2009) published a review on the one hundred years of commercial food carbohydrates in the United States. In this review, the author cites that a spontaneous mutant of corn, called waxy corn, that produces all-amylopectin starch, originated in China, was first reported in 1908. One year later, it was taken to the United States and maintained in agricultural experiment station nurseries as a curiosity. During World War II, when cassava starch importation from Southeast Asia became endangered, the search for a substitute to that desirable food ingredient started. A new starch that would give similar clear, non-gelling pastes was necessary. And the waxy corn starch was found to be a suitable replacement for cassava starch. Hybridization and commercialization quickly followed. Pastes of native waxy corn starch have high viscosity and a long texture, being slightly cloudy and exhibiting a very low tendency to gel, making it more like the pastes from tapioca and potato starches than those made from normal corn and other normal cereal starches. Waxy corn starch became the base starch of choice for many food applications in the United States. The pastes of native waxy corn starch, however, are too stringy and cohesive and break down too easily under shear to be acceptable for many food applications. By using proper chemical modifications, like cross linking and stabilization, waxy corn starch produces pastes of good clarity and stability and a relatively high viscosity, what makes it the starch of choice in the United States for producing modified food starches.

In Brazil, although there is a high production of cassava roots, its processing for starch is relatively low if compared to the Brazilian corn starch production. If only the production of modified cassava starch is considered, then our global participation is very limited (CEREDA; VILPOUX; DEMIATE, 2003); there is a growing demand in the local market for these modified starches, though.

In the present paper, modified commercial starches from cassava were collected and analyzed for selected physicochemical characteristics of interest to the food processing industry. All samples were of food-grade starches and were available in the Brazilian market.

\section{Materials and methods}

\subsection{Materials}

A survey was made considering the commercially available food-grade cassava starches in the Brazilian market in 2007. These starches are used as thickeners, stabilizers, emulsifiers, ingredients for the production of salty expanded biscuits and cheese rolls. This survey was made by using the Internet and also by contacting the main starch companies operating in Brazil.

Cassava starch samples were received from producers or bought in supermarkets during the year of 2007 , including samples of native starch and of sour cassava starch (polvilho azedo).

The starch samples were evaluated in relation to selected physicochemical characteristics, including moisture content, $\mathrm{pH}$, acidity, paste clarity, resistance of the pastes to freeze-thawing, swelling power and solubility, and also rheological properties (apparent viscosity and viscoelasticity).

In this paper, 32 samples were studied: one of native starch, 21 of modified starches and 10 of sour cassava starch. The samples coded from 1 to 6 and from 17 to 31 were modified starches, whereas those from 7 to 16 were sour cassava starches and that coded as 32 was native starch.

\subsection{Methods}

\section{Moisture}

The moisture was determined gravimetrically after drying the samples in oven for five hours at $105^{\circ} \mathrm{C}$ (INSTITUTO..., 1985). Two repetitions were made for this analysis. 
$p H$

In order to measure the $\mathrm{pH}, 20 \mathrm{~g}$ of sample were weighed and suspended in $100 \mathrm{~mL}$ of distilled water being stirred for 30 minutes. After this period, the $\mathrm{pH}$ was measured directly using a calibrated $\mathrm{pH}$ potentiometer (SMITH, 1967) at room temperature $\left(20^{\circ} \mathrm{C}\right)$. Three repetitions were made for this analysis.

Acidity

For acidity measurement, $10 \mathrm{~g}$ of sample were suspended in $50 \mathrm{~mL}$ of distilled water and kept in suspension for 30 minutes at room temperature. After this period, the suspension was transferred to centrifuge tubes and centrifuged for 2 minutes. Half of the volume ( $30 \mathrm{~mL}$ of the clear supernatant) were taken and titrated with $0.01 \mathrm{M} \mathrm{NaOH}$. The acidity was expressed as $\mathrm{mL}$ of $\mathrm{NaOH} 1 \mathrm{~m} .100 \mathrm{~g}^{-1}$ of starch (dry mass). Three repetitions were made for this analysis.

\section{Swelling power and solubility}

These analyses were made at temperatures 50, 60, 70, 80 and $90^{\circ} \mathrm{C}$, as described by Leach, McCowen and Schoch (1959). The starch suspensions were heated on centrifuge tubes for 30 minutes under agitation. After this period, the tubes were centrifuged at 2,000 $\mathrm{g}$ for 10 minutes in order to separate the swollen granules from the soluble starch fraction. The soluble supernatant fraction was collected and dried on oven for quantification. The gel pellet was weighed and the swelling power expressed as times of weight increment in relation to the amount of starch in the initial dispersion. The solubility was calculated as percentage $(\mathrm{w} / \mathrm{w})$ of the initial amount of starch in the dispersion. Two repetitions were made for these analyses.

\section{Paste clarity}

The transmittance of a $1 \%$ starch paste, measured at $650 \mathrm{~nm}$ was considered as paste clarity, as described by Craig et al. (1989). Starch dispersion was heated to boiling (around $98^{\circ} \mathrm{C}$ ) for 30 minutes in order to promote complete gelatinization of the granules. The transmittance was measured after cooling the pastes to $20^{\circ} \mathrm{C}$. The results are averages of three repetitions.

\section{Resistance to freeze-thawing}

Starch pastes at $10 \%$ were frozen stored at $-18^{\circ} \mathrm{C}$ for 72 hours in hermetic plastic cups and the amount of liquid liberated after thawing $\left(45^{\circ} \mathrm{C} / 3\right.$ hours) was measured gravimetrically (CEREDA; WOSIACKI, 1985). The amount of liberated solution was expressed as percentage of weight loss from the initial paste mass. Two repetitions were made for this analysis.

\section{Viscoelasticity of the pastes}

The viscoelastic characteristic of the pastes was studied as described by Kite, Maywald and Schoch (1963) and employed by Cereda and Wosiacki (1985). A 5\% starch paste was poured onto a Petri dish and a straight line was made on the paste surface with a special ink. The distortion promoted on this line by a transversal cut was registered on a filter paper. The results were registered as drawings made on the filter papers.

\section{Apparent viscosity}

The apparent viscosity of the starches, expressed as \% torque, was evaluated using a RVDV-II + PRO Brookfield viscosimeter (maximum torque of 7,187 dyn $\mathrm{cm}$ ) coupled with a water circulator with programmed temperature (Starch System Brookfield ${ }^{\oplus}$ - SSB; bath Brookfield ${ }^{\circledR}$ model TC112P). This system is a cheaper alternative to the RVA and the Brabender viscoamylographs and enables the evaluation of viscosity during the heating and cooling of the starch paste (SHI; BEMILLER, 2002). The system was equipped with a small sample adaptor (model SC4-13RPY) and a special spindle model MVS1Y Flag Impeller Spindle for suspensions. The entire system was controlled by the Rheocalc ${ }^{\circledast}$ software. The starches were weighed (0.8 g dry mass) directly into the small sample adaptor and distilled water was added to complete $12 \mathrm{~g}$. The analysis was made at $160 \mathrm{rpm}$ and the water bath was stabilized at $50{ }^{\circ} \mathrm{C}$. After one minute, the temperature was raised as fast as possible to $95^{\circ} \mathrm{C}$ and kept at this level for five minutes. After this period, the bath was programmed to decrease the temperature to $50{ }^{\circ} \mathrm{C}$ and keep it at this level for 2 minutes, when the analysis was finished. In order to compare the methods, the apparent viscosity was also evaluated employing the Rapid Viscoanalyser ${ }^{\circ}$ (RVA $4^{\oplus}$, Newport Scientific, Narabeen, Australia) by weighing $1.8 \mathrm{~g}$ of starch (DM) and completing the aluminum canister to $27 \mathrm{~g}$ with distilled water. The STD1 temperature profile one minute at $50{ }^{\circ} \mathrm{C}$ followed by heating at $6{ }^{\circ} \mathrm{C} /$ minute until $95^{\circ} \mathrm{C}$, keeping at $95^{\circ} \mathrm{C}$ for 2.5 minutes, cooling until $50{ }^{\circ} \mathrm{C}$ at $6{ }^{\circ} \mathrm{C} /$ minute and keeping at $50{ }^{\circ} \mathrm{C}$ for 2 minutes - was used for analyzing the starch samples.

\section{Results and discussion}

According to the survey, three main American companies were identified in Brazil and starches from their food applications portfolio were considered in the present study. The sour cassava starches were bought in supermarkets in the State of Parana and two other modified samples were produced by national companies. The most used starches for producing modifications are those from waxy corn and cassava, as already shown by Silva et al. (2006). Although in Brazil cassava production is abundant, it seems that more modified starches from waxy corn are available on the market than from cassava. This was not expected, but it can be explained due to the fact that companies develop their products abroad, mainly in the USA, where waxy corn starch is available at relatively low cost. Another thing to be considered is that the Brazilian cassava starch market is very dependent on cassava roots availability and annual prices. As cassava is a perishable raw material, stocks are not as available as those of corn and other agricultural commodities.

This study also detected that the most important modified starch producers are global players with many industrial plants all around the world. Domestic companies lack the technology to develop, produce and commercialize high-value modified starches for the food industry in large scale for the local and export markets. 
The commercial starches analyzed in this study are briefly described in Table 1, identifying some characteristics of interest for food applications.

\section{Characterization of the cassava starches}

Moisture contents of the starches were evaluated just after receiving the samples from the companies or from the supermarkets. The values of moisture varied from $3.8 \pm 0.1$ to $13.9 \% \pm 0.5$ (average \pm standard deviation), in a range accepted by the Brazilian legislation (BRASIL, 2005) that, for native cassava starch, establishes the maximum moisture limit of $18.0 \%$. The lowest moisture value was found for a pre-gelatinized modified starch and the highest for a sample of sour cassava starch.

\section{pH and acidity}

The samples 21, 22, 23 and 26 are pre-gelatinized modified starches. In this case, it was not possible to measure the acidity through the employed methodology due to the high viscosity of the samples. The $\mathrm{pH}$ values ranged from $2.79 \pm 0.14$ to $6.11 \pm 0.23$, whereas the acidity varied from $0.22 \pm 0.02$ to $8.63 \pm 0.24 \mathrm{~mL}$ of
$\mathrm{NaOH} 1 \mathrm{~N} .100 \mathrm{~g}^{-1}$ of sample. Cassava native starch presented a $\mathrm{pH}$ value of $4.99 \pm 0.01$ and acidity corresponding to $0.75 \pm$ $0.13 \mathrm{~mL}$ of $\mathrm{NaOH} 1 \mathrm{~N} .100 \mathrm{~g}^{-1}$ of starch. As expected, the sour cassava starches presented low $\mathrm{pH}(2.92 \pm 0.15$ to $4.03 \pm 0.19)$ and high acidity values $(3.10 \pm 0.12$ to $8.63 \pm 0.24 \mathrm{~mL}$ of $\mathrm{NaOH}$ 1 N.100 g-1 of starch) (CEREDA; LIMA, 1985; DEMIATE et al., 1999; MESTRES; ROUAU, 1997; PETRUCELLI et al., 1983). The lowest $\mathrm{pH}$ value $(2.79 \pm 0.14)$ was found for sample 20 - a food grade dextrin.

\section{Swelling power and solubility}

The swelling power and solubility values of the starches are shown in Table 2.

The swelling power and solubility of the samples increased with the temperature, as expected, due to starch granule cooking under excess of water. The values varied very much at different temperatures, but it is possible to note that the native and the sour starch samples had relatively high swelling powers at 80 and $90{ }^{\circ} \mathrm{C}$ (values close to 20 times or over) as well as samples 4,17 , $18,19,23,25$ and 28. All these samples, as shown in Figures 2

Table 1. Codified cassava starches and selected characteristics.

\begin{tabular}{|c|c|}
\hline Sample & Summarized description/food application \\
\hline 1 & $\begin{array}{l}\text { Multipurpose thickener for applications that require high viscosity and stability. This starch presents high stability to freeze-thawing } \\
\text { and to low- temperature storage, recommended for frozen foods. }\end{array}$ \\
\hline 2 & $\begin{array}{l}\text { Presents bland flavor and is a process resistant thickener. It is very stable to refrigerated storage and is resistant to heat and acidic con- } \\
\text { ditions. It is recommended for use in relatively bland flavor foods (fillings, puddings, dairy products). }\end{array}$ \\
\hline 3 & $\begin{array}{l}\text { Thickener with bland flavor results in smooth and short texture with many applications in processed foods. It is well suited for bland } \\
\text { flavor foods as fillings, sauces and gravies and also improves low temperature stability of frozen prepared foods. }\end{array}$ \\
\hline 4 & $\begin{array}{l}\text { Modified starch with medium to high viscosity that offers high clarity and brightness and excellent tolerance to high temperatures and } \\
\text { shear without losing its characteristic. It is used on melted cheeses (regular or light) and on creamy cheeses (petit-suisse). }\end{array}$ \\
\hline 5 & $\begin{array}{l}\text { Modified starch for applications in meat products including sausages, ham-like products, patés, cooked ham. It reduces the amount of exu- } \\
\text { dation inside vacuum packs and also the weight loss during oven cooking resulting in creamy aspect and increasing the brine injection. }\end{array}$ \\
\hline 6 & $\begin{array}{l}\text { Jellifying agent that resists to retrogradation. It produces stable emulsion in refrigerator temperature, resists to syneresis, low } \mathrm{pH} \text { values } \\
\text { and high temperatures. It promotes gel formation with smooth and short texture. Its main applications are in cakes, canned meats. } \\
\text { confectionary cream, diet/light meat products, fillings, desserts and powder soups }\end{array}$ \\
\hline 7-16 & Sour cassava starch. \\
\hline 17 & $\begin{array}{l}\text { Mixtures for cheese bread (powder or frozen balls). It produces the typical texture, elasticity and is responsible for the internal structu- } \\
\text { re and expansion of the cheese bread. }\end{array}$ \\
\hline 18 & $\begin{array}{l}\text { Jellifying agent, resistant to retrogradation, promoting formation of a smooth and short gel when compared to regular starch. Resists } \\
\text { to syneresis, to low temperatures and also to sterilizing temperatures. Its main applications are in infant foods, confectionary cream, } \\
\text { jellies, ready-to-eat frozen dishes and powder desserts. }\end{array}$ \\
\hline 19 & $\begin{array}{l}\text { Instant mixtures for cheese breads and frozen cheese breads (balls). It produces the typical texture, elasticity, and may be used together } \\
\text { with native cassava starch improving texture and volume of the products. Responsible for internal structure and expansion of the } \\
\text { cheese bread. }\end{array}$ \\
\hline 20 & $\begin{array}{l}\text { Food dextrin with light color, high adhesivity and good film formation. In aqueous solution presents clear color, low viscosity, high } \\
\text { solubility, easy dispersion and produces cold suspension. Its main applications are as flavor encapsulation, glacés, creams and fillings. }\end{array}$ \\
\hline 21 & Cross-linked cassava starch, used in mixtures for baking products, sauces, instant soups, puddings, creams, desserts and cheese breads. \\
\hline $22-23$ & Pre-gelatinized modified starch. \\
\hline 24 & $\begin{array}{l}\text { Modified starch for applications that require resistance to freeze-thawing, with high stability of the final product. Its main applications } \\
\text { are on mixtures for baking products, refrigerated sauces, milky products, yogurts. }\end{array}$ \\
\hline 25 & $\begin{array}{l}\text { Modified starch for multiple purpose, for processes that require resistance to high temperatures, acidity and mechanical shearing. It } \\
\text { presents smooth flavor and gel stability. Its main applications are in fruit preparations, acid fillings, canned soups, acid sauces, thermal } \\
\text { processed foods, mayonnaise type sauces. }\end{array}$ \\
\hline 26 & Pre-gelatinized modified starch. \\
\hline 27-31 & Modified starch - information not available. \\
\hline 32 (Native) & Cassava native starch. \\
\hline
\end{tabular}


to 5 , presented a viscosity peak during stirred cooking of $6.67 \%$ starch slurries in the viscoamylographic analysis. For solubility, also the native and sour cassava starches presented high values, over $30 \%$ at 80 and $90{ }^{\circ} \mathrm{C}$, as well as the samples coded 4,6 , $17,19,20$ and 23 . As the sample 20 is a dextrin, its very high solubility in all tested temperatures was expected.

\section{Paste clarity}

The values of transmittance of the $1 \%$ starch pastes of the native and modified starches are shown in Table 3.

The values of transmittance showed that sour cassava starches produced pastes with clarity values higher than those of native cassava starch. The other modified starches had different patterns, but most samples produced pastes with lower clarity values than native starch, what means more opaque pastes with granules less swollen, more difficult to cook. If we compare the results shown in Table 3 with that of Figure 1, it is possible to associate the higher transmittance values with the samples that presented long rheology. The other samples, with low paste clarity (transmittance lower than $25.1 \%$ ), presented short rheology. As expected, the dextrin sample had a very high clarity value.

\section{Resistance to freeze-thawing}

The liberation of liquid from starch pastes due to freezing and thawing is shown in Table 4.

Sample \#20 is a food dextrin that produced a very fluid paste and it was not possible to measure the liberated fluid during freeze-thawing through the employed methodology. Cassava native starch is known for its resistance to retrogradation and syneresis. The modified starches derived from this source also presented low fluid exudation after freeze and thawing, which was expected. Only the sour cassava starch samples presented higher tendency to retrogradation and syneresis, as shown in Table 4. In many food applications this characteristic is undesirable and this may explain why most of the available commercial modified starches presented low fluid liberation. It is important to note that, even after chemical modification,

Table 2. Swelling power and solubility of the starch samples.

\begin{tabular}{|c|c|c|c|c|c|c|c|c|c|c|}
\hline \multirow[t]{2}{*}{ Sample } & \multicolumn{5}{|c|}{ Swelling power (times) } & \multicolumn{5}{|c|}{ Solubility (\%) } \\
\hline & $50{ }^{\circ} \mathrm{C}$ & $60^{\circ} \mathrm{C}$ & $70^{\circ} \mathrm{C}$ & $80^{\circ} \mathrm{C}$ & $90^{\circ} \mathrm{C}$ & $50^{\circ} \mathrm{C}$ & $60^{\circ} \mathrm{C}$ & $70^{\circ} \mathrm{C}$ & $80^{\circ} \mathrm{C}$ & $90^{\circ} \mathrm{C}$ \\
\hline Native & $3.1 \pm 0.3$ & $10.3 \pm 0.8$ & $21.1 \pm 8.7$ & $24.5 \pm 4.1$ & $22.3 \pm 9.3$ & $0.8 \pm 0.0$ & $4.9 \pm 0.6$ & $11.8 \pm 8.7$ & $43.5 \pm 32.3$ & $33.5 \pm 22.3$ \\
\hline 1 & $5.6 \pm 1.7$ & $10.7 \pm 0.8$ & $12.1 \pm 0.5$ & $12.5 \pm 1.7$ & $12.9 \pm 0.9$ & $0.9 \pm 1.2$ & $2.8 \pm 0.8$ & $3.4 \pm 0.4$ & $12.9 \pm 11.5$ & $12.1 \pm 9.3$ \\
\hline 2 & $13.4 \pm 2.2$ & $12.2 \pm 0.7$ & $12.8 \pm 0.5$ & $12.8 \pm 0.9$ & $13.1 \pm 1.5$ & $4.5 \pm 0.7$ & $5.8 \pm 0.6$ & $6.4 \pm 0.7$ & $14.0 \pm 9.6$ & $15.4 \pm 10.2$ \\
\hline 3 & $5.8 \pm 2.1$ & $10.3 \pm 0.4$ & $11.8 \pm 0.5$ & $12.0 \pm 0.9$ & $12.0 \pm 0.8$ & $1.9 \pm 0.4$ & $6.9 \pm 1.0$ & $8.1 \pm 0.3$ & $21.7 \pm 15.9$ & $24.8 \pm 19.1$ \\
\hline 4 & $7.5 \pm 1.5$ & $17.2 \pm 0.9$ & $21.0 \pm 3.2$ & $19.5 \pm 5.9$ & $22.1 \pm 2.2$ & $1.5 \pm 1.2$ & $10.3 \pm 1.9$ & $16.6 \pm 0.9$ & $32.3 \pm 18.8$ & $40.5 \pm 28.4$ \\
\hline 5 & $4.9 \pm 2.2$ & $9.7 \pm 0.6$ & $11.8 \pm 0.7$ & $12.5 \pm 0.8$ & $12.9 \pm 0.4$ & $0.7 \pm 0.8$ & $5.0 \pm 0.8$ & $7.0 \pm 0.5$ & $20.0 \pm 14.4$ & $20.3 \pm 14.1$ \\
\hline 6 & $2.1 \pm 0.1$ & $6.7 \pm 1.7$ & $11.8 \pm 0.5$ & $12.5 \pm 0.3$ & $12.3 \pm 1.1$ & $0.0 \pm 0.0$ & $4.1 \pm 1.0$ & $9.6 \pm 3.3$ & $12.4 \pm 4.4$ & $27.0 \pm 13.1$ \\
\hline 7 & $2.6 \pm 0.7$ & $8.8 \pm 3.5$ & $25.5 \pm 3.7$ & $29.9 \pm 6.9$ & $28.6 \pm 0.6$ & $2.8 \pm 1.8$ & $8.9 \pm 5.5$ & $32.6 \pm 0.3$ & $38.0 \pm 2.9$ & $53.5 \pm 1.2$ \\
\hline 8 & $2.4 \pm 0.6$ & $10.4 \pm 3.7$ & $15.0 \pm 9.4$ & $25.4 \pm 3.3$ & $23.9 \pm 0.1$ & $1.0 \pm 0.9$ & $9.7 \pm 5.1$ & $26.1 \pm 1.1$ & $32.7 \pm 1.6$ & $43.9 \pm 4.8$ \\
\hline 9 & $2.6 \pm 0.8$ & $8.3 \pm 5.0$ & $24.1 \pm 6.4$ & $20.2 \pm 5.5$ & $25.4 \pm 1.4$ & $5.3 \pm 6.5$ & $15.2 \pm 9.8$ & $47.3 \pm 2.8$ & $52.7 \pm 7.3$ & $68.7 \pm 0.6$ \\
\hline 10 & $2.3 \pm 0.7$ & $7.7 \pm 3.8$ & $23.5 \pm 1.8$ & $23.6 \pm 8.2$ & $21.7 \pm 0.1$ & $1.9 \pm 1.3$ & $14.4 \pm 9.9$ & $52.7 \pm 5.9$ & $56.7 \pm 0.0$ & $71.1 \pm 7.1$ \\
\hline 11 & $2.4 \pm 0.6$ & $8.4 \pm 4.9$ & $26.1 \pm 0.8$ & $25.4 \pm 5.1$ & $28.9 \pm 2.1$ & $2.4 \pm 2.8$ & $10.9 \pm 8.2$ & $39.4 \pm 1.7$ & $49.2 \pm 2.7$ & $63.9 \pm 7.7$ \\
\hline 12 & $2.6 \pm 0.8$ & $8.4 \pm 3.9$ & $24.2 \pm 0.8$ & $24.0 \pm 0.8$ & $18.3 \pm 2.9$ & $4.4 \pm 4.7$ & $13.0 \pm 7.7$ & $44.3 \pm 1.7$ & $49.7 \pm 2.0$ & $68.6 \pm 4.6$ \\
\hline 13 & $2.6 \pm 0.7$ & $10.5 \pm 4.2$ & $25.8 \pm 0.3$ & $27.3 \pm 1.9$ & $24.2 \pm 2.2$ & $3.7 \pm 3.8$ & $14.6 \pm 7.7$ & $42.1 \pm 4.5$ & $47.4 \pm 3.4$ & $66.5 \pm 7.4$ \\
\hline 14 & $5.9 \pm 5.5$ & $15.1 \pm 9.5$ & $28.4 \pm 2.7$ & $31.6 \pm 2.7$ & $27.8 \pm 6.8$ & $6.1 \pm 7.4$ & $22.7 \pm 18.8$ & $40.6 \pm 3.5$ & $47.9 \pm 6.6$ & $71.7 \pm 15.2$ \\
\hline 15 & $3.9 \pm 2.7$ & $12.8 \pm 10.4$ & $25.0 \pm 2.8$ & $24.5 \pm 0.3$ & $18.9 \pm 3.8$ & $6.9 \pm 8.1$ & $22.6 \pm 20.5$ & $43.9 \pm 1.2$ & $54.9 \pm 6.0$ & $42.0 \pm 28.2$ \\
\hline 16 & $3.5 \pm 1.9$ & $12.2 \pm 9.7$ & $22.2 \pm 1.1$ & $21.5 \pm 1.6$ & $17.1 \pm 8.6$ & $3.1 \pm 3.4$ & $22.0 \pm 18.2$ & $47.8 \pm 0.4$ & $59.3 \pm 1.8$ & $81.6 \pm 21.7$ \\
\hline 17 & $4.7 \pm 0.9$ & $21.4 \pm 9.1$ & $31.4 \pm 6.0$ & $41.4 \pm 10.5$ & $47.6 \pm 1.9$ & $1.6 \pm 0.1$ & $10.2 \pm 2.7$ & $19.3 \pm 4.6$ & $30.5 \pm 12.7$ & $42.4 \pm 10.4$ \\
\hline 18 & $4.1 \pm 1.1$ & $12.9 \pm 1.8$ & $16.3 \pm 2.3$ & $17.7 \pm 2.8$ & $18.1 \pm 2.1$ & $3.3 \pm 1.0$ & $13.9 \pm 1.5$ & $18.4 \pm 3.4$ & $22.9 \pm 4.8$ & $25.6 \pm 4.3$ \\
\hline 19 & $2.6 \pm 0.4$ & $15.1 \pm 7.4$ & $29.6 \pm 5.4$ & $40.3 \pm 17.9$ & $35.6 \pm 2.6$ & $1.2 \pm 0.3$ & $15.5 \pm 4.6$ & $32.2 \pm 6.0$ & $44.6 \pm 13.9$ & $56.7 \pm 7.3$ \\
\hline 20 & $0.4 \pm 0.3$ & $0.4 \pm 0.1$ & $0.5 \pm 0.0$ & $0.3 \pm 0.1$ & $0.4 \pm 0.0$ & $90.9 \pm 3.2$ & $90.7 \pm 1.0$ & $90.7 \pm 1.4$ & $96.3 \pm 2.1$ & $95.9 \pm 0.0$ \\
\hline 21 & $12.1 \pm .5$ & $12.1 \pm 0.9$ & $12.9 \pm 0.9$ & $12.6 \pm 0.1$ & $12.1 \pm 0.1$ & $15.2 \pm 1.4$ & $15.5 \pm 1.2$ & $15.6 \pm 1.6$ & $17.8 \pm 2.2$ & $21.1 \pm 3.0$ \\
\hline 22 & $13.3 \pm 0.1$ & $13.8 \pm 1.7$ & $14.0 \pm 2.0$ & $12.9 \pm 0.1$ & $13.6 \pm 0.7$ & $20.4 \pm 0.0$ & $22.7 \pm 0.1$ & $24.6 \pm 4.4$ & $22.8 \pm 0.3$ & $27.5 \pm 1.5$ \\
\hline 23 & $12.9 \pm 4.0$ & $14.6 \pm 0.1$ & $15.6 \pm 7.5$ & $17.0 \pm 5.6$ & $17.0 \pm 6.2$ & $43.6 \pm 15.9$ & $35.5 \pm 2.5$ & $38.1 \pm 4.9$ & $48.4 \pm 7.7$ & $71.8 \pm 6.3$ \\
\hline 24 & $4.3 \pm 0.9$ & $11.2 \pm 1.7$ & $12.2 \pm 1.3$ & $12.1 \pm 0.7$ & $12.9 \pm 0.7$ & $0.4 \pm 0.05$ & $6.5 \pm 2.3$ & $5.2 \pm 2.5$ & $7.5 \pm 1.4$ & $10.3 \pm 0.3$ \\
\hline 25 & $4.9 \pm 0.9$ & $16.9 \pm 4.4$ & $25.9 \pm 5.4$ & $26.9 \pm 1.3$ & $31.5 \pm 0.8$ & $1.7 \pm 0.4$ & $6.9 \pm 1.5$ & $8.9 \pm 0.2$ & $13.9 \pm 2.1$ & $16.9 \pm 0.3$ \\
\hline 26 & $13.9 \pm 0.6$ & $14.3 \pm 1.3$ & $15.6 \pm 1.3$ & $16.2 \pm 0.6$ & $15.5 \pm 0.5$ & $15.1 \pm 2.6$ & $16.3 \pm 0.6$ & $18.6 \pm 3.1$ & $19.8 \pm 4.7$ & $22.1 \pm 3.5$ \\
\hline 27 & $2.2 \pm 0.4$ & $7.0 \pm 1.2$ & $12.0 \pm 0.2$ & $12.6 \pm 0.8$ & $13.1 \pm 1.1$ & $0.2 \pm 0.0$ & $2.7 \pm 1.0$ & $7.1 \pm 0.8$ & $9.1 \pm 2.1$ & $10.9 \pm 1.7$ \\
\hline 28 & $4.5 \pm 1.3$ & $12.3 \pm 0.5$ & $16.5 \pm 0.3$ & $17.0 \pm 1.3$ & $17.3 \pm 0.2$ & $1.6 \pm 0.7$ & $5.4 \pm 1.4$ & $9.2 \pm 1.3$ & $11.3 \pm 1.5$ & $12.6 \pm 1.1$ \\
\hline 29 & $8.7 \pm 1.1$ & $12.3 \pm 1.2$ & $14.1 \pm 0.5$ & $14.3 \pm 1.3$ & $14.4 \pm 0.4$ & $2.7 \pm 0.5$ & $3.9 \pm 0.2$ & $5.4 \pm 0.7$ & $6.9 \pm 1.5$ & $7.5 \pm 1.0$ \\
\hline 30 & $2.3 \pm 0.2$ & $6.4 \pm 2.5$ & $14.2 \pm 0.8$ & $14.1 \pm 1.2$ & $13.9 \pm 0.3$ & $0.6 \pm 0.3$ & $1.2 \pm 0.3$ & $2.1 \pm 0.7$ & $2.4 \pm 0.3$ & $3.4 \pm 0.5$ \\
\hline 31 & $2.3 \pm 0.1$ & $6.2 \pm 2.7$ & $13.9 \pm 0.1$ & $13.9 \pm 1.3$ & $13.8 \pm 0.3$ & $1.1 \pm 0.5$ & $1.4 \pm 0.1$ & $2.6 \pm 0.6$ & $2.8 \pm 0.4$ & $3.5 \pm 0.4$ \\
\hline
\end{tabular}




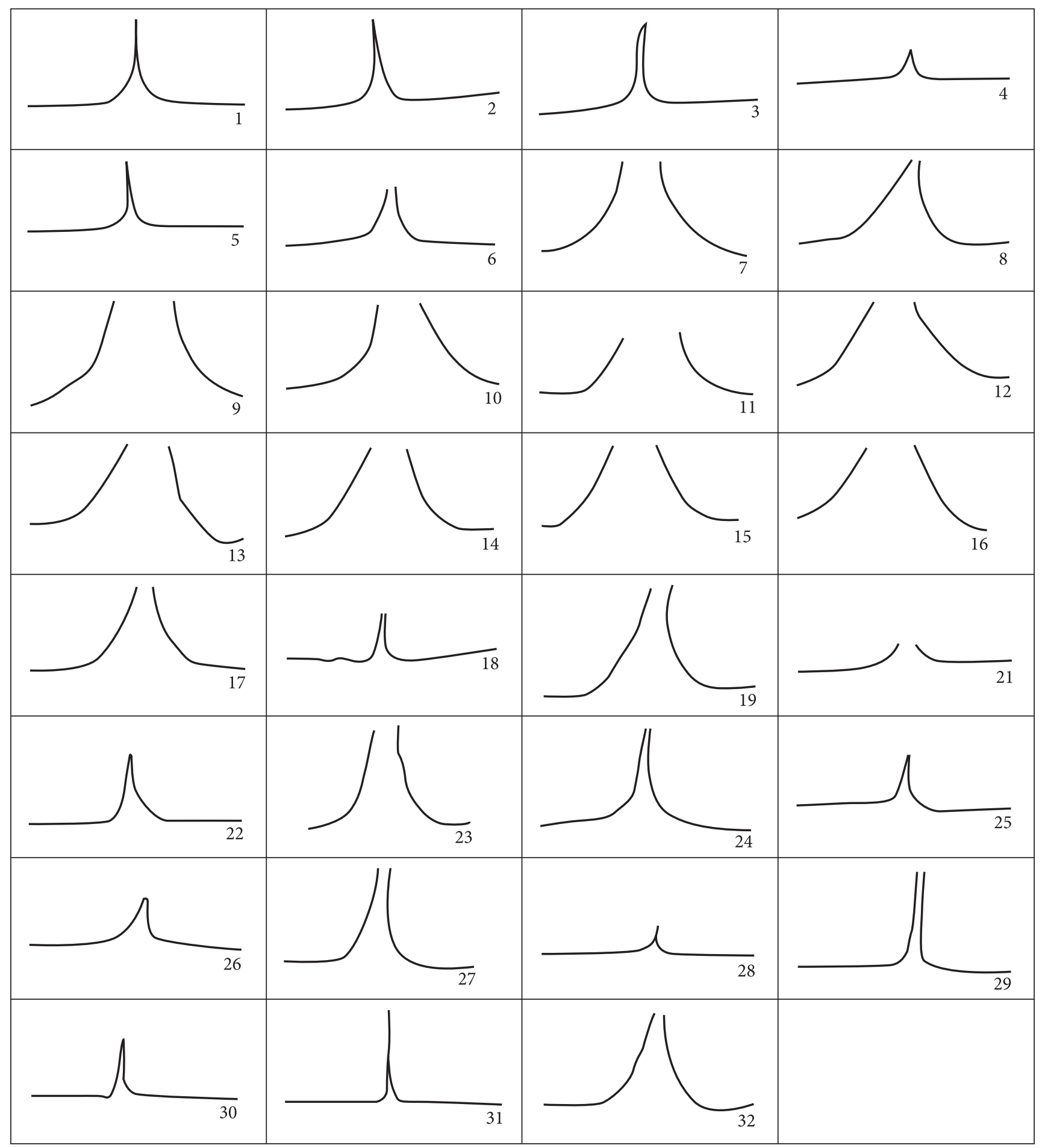

Figure 1. Viscoelasticity of cassava starch pastes.

it is interesting to maintain some desired characteristics of the native starch, as the low tendency to retrogradation presented by cassava starch.

\section{Paste viscoelasticity}

The viscoelasticity was evaluated and the results are presented as drawings in Figure 1, varying from "short" to "long" rheology or texture (CEREDA; WOSIACKI, 1985).
The "short" rheology is associated to regular corn starch and the "long" rheology to cassava starch (CEREDA; WOSIACKI, 1985). The results presented in Figure 1 show that the modified starches have distinct patterns when compared to the native one (sample 32). Sour cassava starches (7 to 16) had a similar behavior to that of the native starch, as well as samples 17 and 19, that are commercialized for producing cheese bread with enhanced expansion. On the other hand, several samples presented a "short" rheology pattern (1 to 6, 18, 21, 22, 24, 25, 
26 and 28 to 31), what can be associated to the smooth, creamy characteristic of the pastes, a desired sensory consistency in many types of foods such as dairy products (yogurt, for example), desserts, puddings, mayonnaise-type sauces, etc.

\section{Apparent viscosity of the starch pastes}

The apparent viscosity behaviors of the $6.67 \% \mathrm{w} / \mathrm{w}$ (d.b.) starch pastes, evaluated by the two following systems (Starch System Brookfield ${ }^{\oplus}$ and Rapid Viscoanalyser ${ }^{\circledast}$ ), are shown in Figures 2 to 5 , where the similar viscographic patterns were grouped. The pre-gel $(19,21,22,23,26)$ and dextrin (20) samples were not assessed in relation to the apparent viscosity pattern.

Through the analysis of the viscoamylograms produced with the alternative Starch System Brookfield ${ }^{\circledR}$

Table 3. Paste clarity of cassava starch pastes.

\begin{tabular}{cccc}
\hline Sample & $\begin{array}{c}\text { Transmittance } \\
(\% \mathrm{~T})\end{array}$ & Sample & $\begin{array}{c}\text { Transmittance } \\
(\% \mathrm{~T})\end{array}$ \\
\hline Native & $45.9 \pm 0.1$ & 16 & $70.9 \pm 0.3$ \\
1 & $9.3 \pm 0.2$ & 17 & $28.8 \pm 0.2$ \\
2 & $13.5 \pm 0.1$ & 18 & $8.7 \pm 0.1$ \\
3 & $15.1 \pm 0.2$ & 19 & $47.8 \pm 0.1$ \\
4 & $24.8 \pm 0.5$ & 20 & $97.8 \pm 0.3$ \\
5 & $14.2 \pm 0.1$ & 21 & $10.8 \pm 0.1$ \\
6 & $17.9 \pm 0.1$ & 22 & $21.9 \pm 0.8$ \\
7 & $66.9 \pm 0.1$ & 23 & $56.2 \pm 0.1$ \\
8 & $60.9 \pm 0.1$ & 24 & $4.4 \pm 0.1$ \\
9 & $78.5 \pm 0.1$ & 25 & $6.1 \pm 0.0$ \\
10 & $75.6 \pm 0.2$ & 26 & $25.1 \pm 0.3$ \\
11 & $70.3 \pm 0.1$ & 27 & $16.0 \pm 0.1$ \\
12 & $69.3 \pm 0.1$ & 28 & $16.9 \pm 0.0$ \\
13 & $68.3 \pm 0.0$ & 29 & $10.8 \pm 0.1$ \\
14 & $72.3 \pm 0.1$ & 30 & $9.3 \pm 0.0$ \\
15 & $69.8 \pm 0.2$ & 31 & $10.4 \pm 0.1$ \\
\hline
\end{tabular}

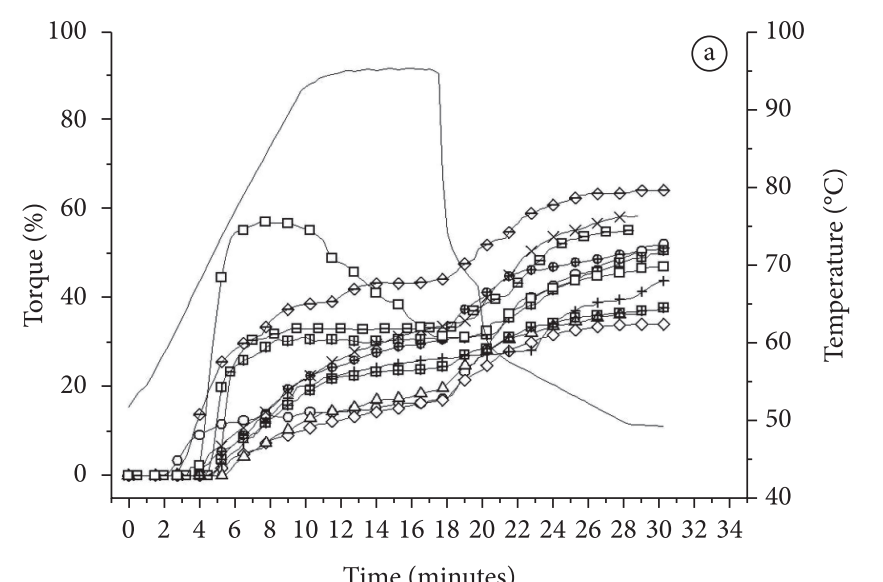

Time (minutes)
(Figures 1 to 4 ), following the same experimental conditions (temperature profile, rotational speed, starch concentration), it was possible to observe the similar pattern of the different starch pastes when compared to the graphs made with the Rapid Viscoanalyser ${ }^{\oplus}\left(\mathrm{RVA}^{\oplus}\right)$ (Figures 2 to 5 ), one of the most used systems for starch cooking analysis.

The Figures 2 to 5 were produced by grouping apparent viscosity patterns during heating and cooling of the starch suspensions at $6.67 \%(\mathrm{w} / \mathrm{w})$. Samples 1 to $3,5,6,24,27$ and 29 to 31 were difficult to cook and showed high tendency to retrogradation. Samples 4, 18, 25 and 28 had high viscosity peaks and tendency to retrogradation when their pastes were cooled until $50^{\circ} \mathrm{C}$ as common characteristics. Samples 17 and 19 were grouped in Figure 4 and presented similar pattern concerning viscosity peak and cooking instability, although sample 17 had a higher viscosity peak. These two modified starches are marketed for producing cheese bread, the same commercial interest of sour cassava starch (Figure 4). Their viscographic behaviors were also related, presenting high cooking instability.

When analyzing the viscographic patterns together with the other parameters, it is possible to confirm that for these samples the most heat stable the pastes, the lower their clarity - a behavior that resembles cereal starch pastes. The results expressed in the Figure 1 for the 32 starch samples are also related to those of the other analyses, and the samples with "short" and "long" rheology are grouped in almost the same manner by their viscographic patterns. Except for the native starch, the sour cassava starches and the cassava starches for cheese bread production, the others showed short rheology, lower paste clarity and lower swelling power, what reveals the main interest of the Brazilian food industry for starches producing smooth, creamy consistency, but with low tendency to retrogradation and syneresis, resisting to processing and cold storage conditions.

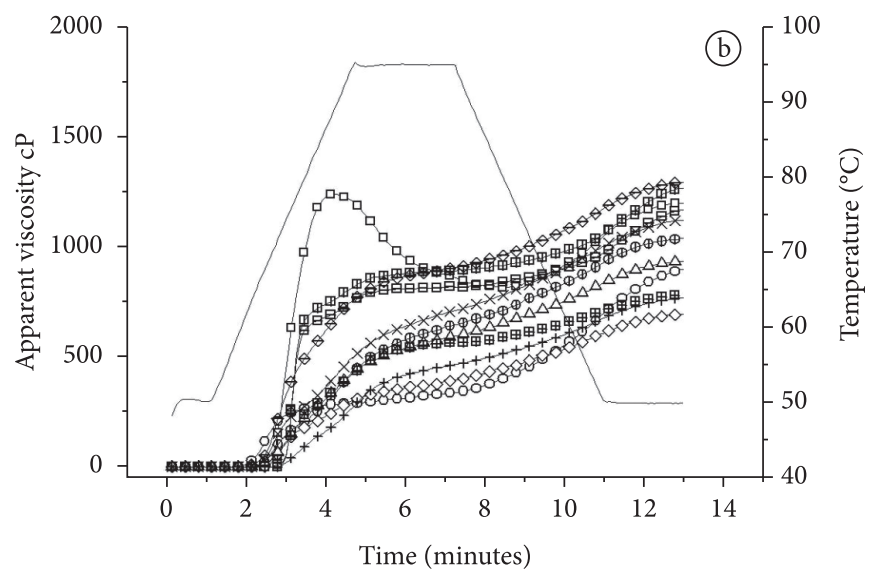

- Temperature $\rightarrow$ - Native $\rightarrow$ Sample $1 \multimap$ Sample $2 \multimap$ Sample $3 \rightarrow \triangle$ Sample 5

$\rightarrow$ Sample $6 \rightarrow$ Sample $24 \rightarrow$ Sample $27 \rightarrow$ Sample $29 \rightarrow$ Sample $30 \rightarrow$ Sample 31

Figure 2. Brookfield (left) and RVA (right) viscoamylograms of of samples 1, 2, 3, 5, 6, 24, 27, 29, 30, 31 and of native cassava starch. 


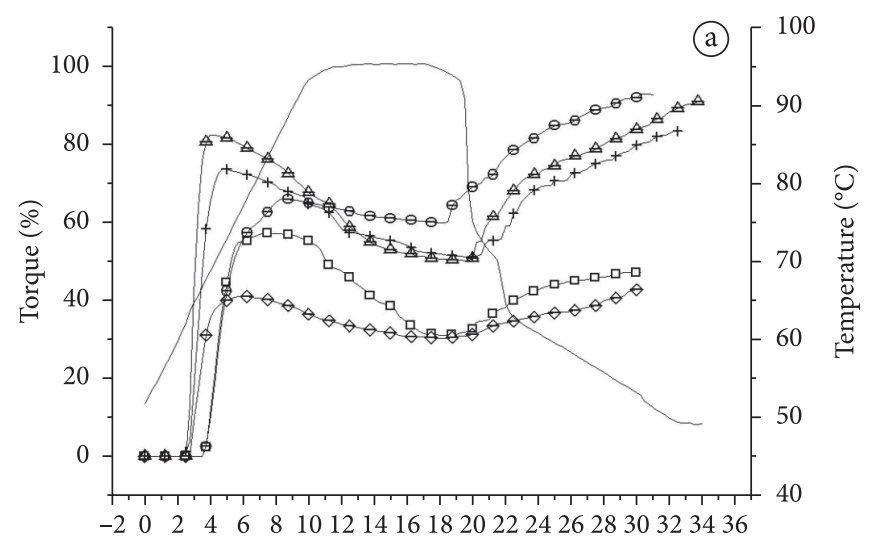

Time (minutes)

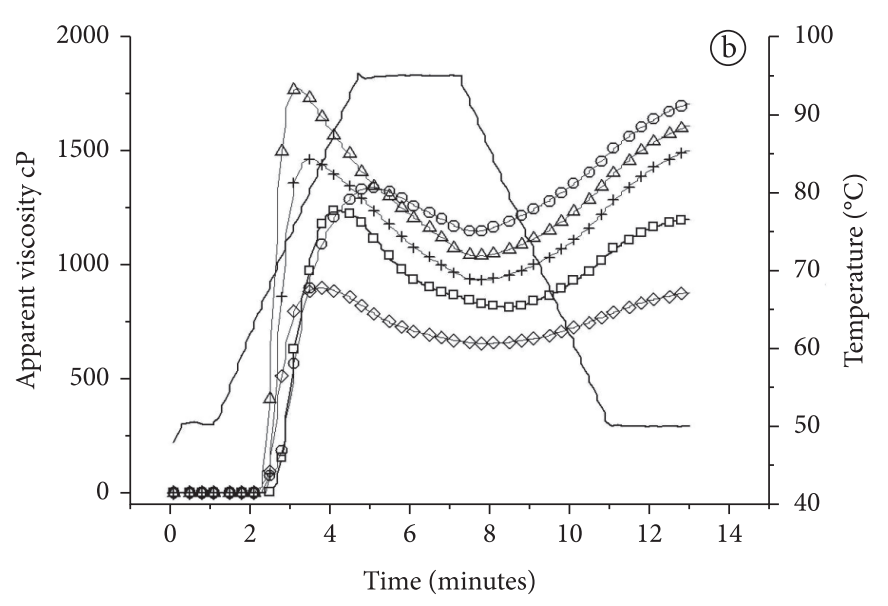

$\leftarrow$ Temperature $\rightarrow$ Native $\triangle$ Sample $4 \rightarrow$ Sample $18 \multimap$ Sample $25 \multimap$ Sample 28

Figure 3. Brookfield (left) and RVA (right) viscoamylograms of samples 4, 18, 25, 28 and of native cassava starch.
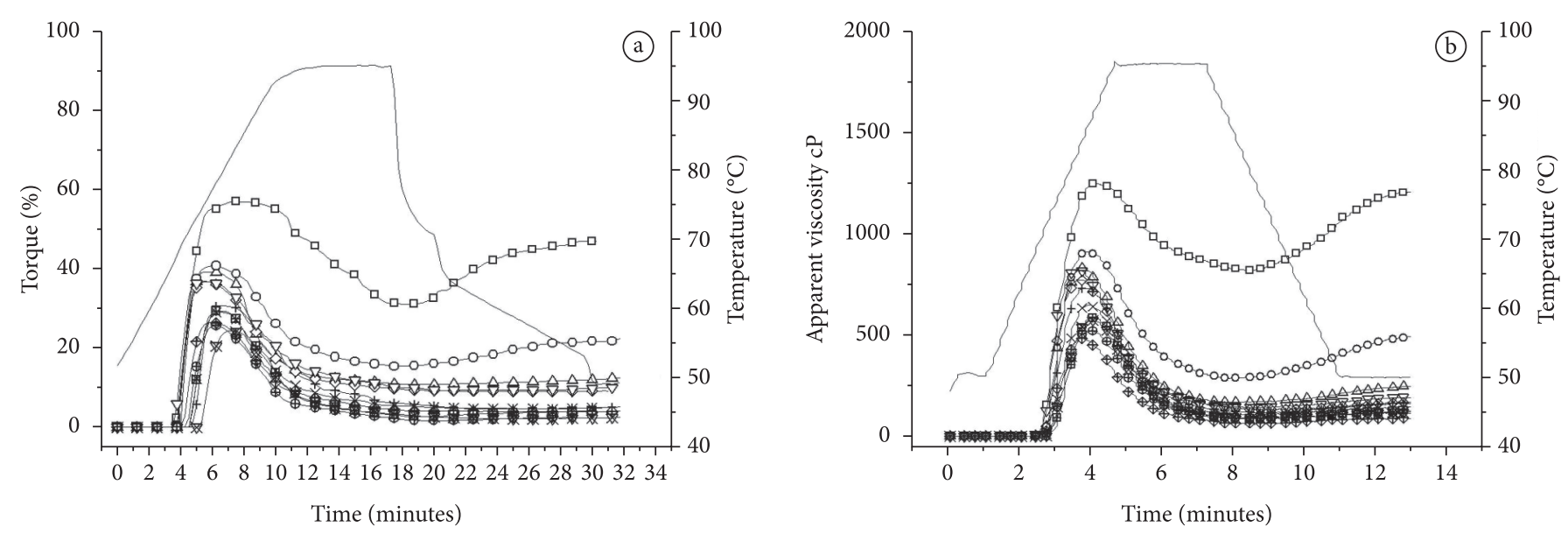

Time (minutes)

\begin{tabular}{llllll}
\hline Temperature & $\rightarrow$ Native & $\rightarrow$ Sample 7 & $\rightarrow$ Sample 8 & $\rightarrow$ Sample 9 & $\rightarrow$ Sample 10 \\
$\rightarrow$ Sample 11 & $\rightarrow$ Sample 12 & $\rightarrow$ Sample 13 & $\rightarrow$ Sample 14 & $\rightarrow$ Sample 15 & $\rightarrow$ Sample 16
\end{tabular}

Figure 4. Brookfield (left) and RVA (right) viscoamylograms of samples 7-16 and of native cassava starch.
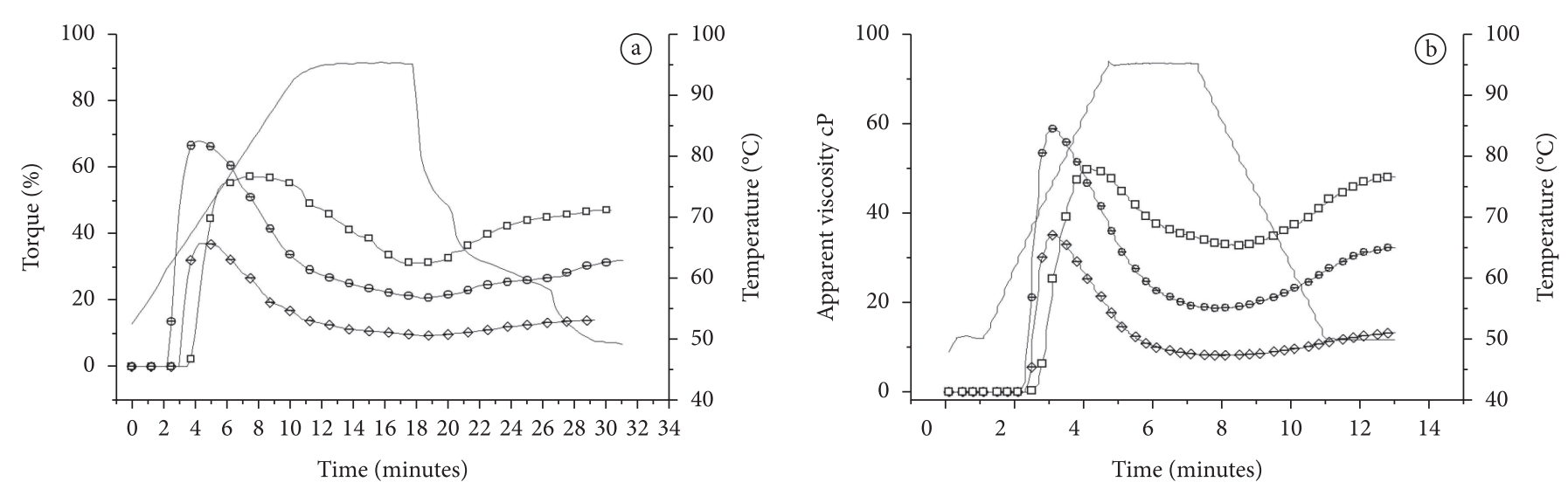

$\longrightarrow$ Temperature $\rightarrow$ Native $\multimap$ Sample $17 \rightarrow$ Sample 19

Figure 5. Brookfield (left) and RVA (right) viscoamylograms of samples 17, 19 and of native cassava starch. 
Table 4. Resistance to freeze-thawing.

\begin{tabular}{|c|c|c|c|}
\hline Sample & $\begin{array}{c}1^{\text {st }} \text { cycle } \\
\text { (\% liberated } \\
\text { fluid) }\end{array}$ & $\begin{array}{c}2^{\text {nd }} \text { cycle } \\
\text { (\% liberated fluid) }\end{array}$ & $\begin{array}{c}3^{\text {rd }} \text { cycle } \\
\text { (\% liberated } \\
\text { fluid) }\end{array}$ \\
\hline Native & $1.5 \pm 0.3$ & $1.0 \pm 0.7$ & $3.5 \pm 3.5$ \\
\hline 1 & $0.9 \pm 1.3$ & $1.2 \pm 1.7$ & $1.4 \pm 1.7$ \\
\hline 2 & $1.1 \pm 1.5$ & $1.3 \pm 1.2$ & $1.6 \pm 1.5$ \\
\hline 3 & $0.4 \pm 0.6$ & $0.9 \pm 1.3$ & $1.5 \pm 1.4$ \\
\hline 4 & $0.5 \pm 0.6$ & 0.91 .2 & $1.2 \pm 1.3$ \\
\hline 5 & $0.4 \pm 0.6$ & $0.8 \pm 1.0$ & $1.1 \pm 1.5$ \\
\hline 6 & $0.4 \pm 0.5$ & $0.6 \pm 0.0$ & $1.9 \pm 1.7$ \\
\hline 7 & $2.6 \pm 1.2$ & $3.1 \pm 0.2$ & $11.6 \pm 8.1$ \\
\hline 8 & $1.5 \pm 1.0$ & $1.6 \pm 0.4$ & $4.4 \pm 0.5$ \\
\hline 9 & $2.4 \pm 0.6$ & $6.7 \pm 2.4$ & $23.7 \pm 17.4$ \\
\hline 10 & $5.1 \pm 0.0$ & $7.8 \pm 2.0$ & $24.9 \pm 16.1$ \\
\hline 11 & $2.1 \pm 0.6$ & $13.2 \pm 7.5$ & $19.6 \pm 17.3$ \\
\hline 12 & $2.4 \pm 0.2$ & $4.7 \pm 3.1$ & $16.8 \pm 16.6$ \\
\hline 13 & $1.6 \pm 0.4$ & $1.7 \pm 2.1$ & $7.3 \pm 4.5$ \\
\hline 14 & $1.7 \pm 1.0$ & $3.5 \pm 0.3$ & $9.2 \pm 4.8$ \\
\hline 15 & $4.2 \pm 0.6$ & $7.1 \pm 3.7$ & $16.3 \pm 11.3$ \\
\hline 16 & $6.5 \pm 0.7$ & $8.7 \pm 3.8$ & $23.3 \pm 16.2$ \\
\hline 17 & $0.4 \pm 0.4$ & $0.4 \pm 0.2$ & $1.0 \pm 0.6$ \\
\hline 18 & $0.6 \pm 0.2$ & $1.2 \pm 1.0$ & $1.6 \pm 1.2$ \\
\hline 19 & $0.5 \pm 0.0$ & $1.6 \pm 0.3$ & $2.9 \pm 2.9$ \\
\hline 20 & $\operatorname{dextrin}\left(^{\star}\right)$ & $\operatorname{dextrin}\left({ }^{*}\right)$ & $\operatorname{dextrin}\left({ }^{*}\right)$ \\
\hline 21 & $2.4 \pm 0.7$ & $5.6 \pm 5.6$ & $5.5 \pm 1.0$ \\
\hline 22 & $0.6 \pm 0.3$ & $0.3 \pm 0.1$ & $0.9 \pm 0.8$ \\
\hline 23 & $0.3 \pm 0.1$ & $1.2 \pm 0.4$ & $2.8 \pm 0.3$ \\
\hline 24 & $0.4 \pm 0.1$ & $0.8 \pm 0.2$ & $1.1 \pm 0.6$ \\
\hline 25 & $0.5 \pm 0.5$ & $0.3 \pm 0.1$ & $0.3 \pm 0.0$ \\
\hline 26 & $0.9 \pm 0.0$ & $0.8 \pm 0.7$ & $3.2 \pm 3.9$ \\
\hline 27 & $4.8 \pm 5.3$ & $10.9 \pm 6.7$ & $14.5 \pm 0.4$ \\
\hline 28 & $1.9 \pm 0.0$ & $2.8 \pm 2.2$ & $0.9 \pm 0.5$ \\
\hline 29 & $1.9 \pm 0.6$ & $1.0 \pm 0.3$ & $1.0 \pm 0.7$ \\
\hline 30 & $1.4 \pm 0.3$ & $1.4 \pm 0.7$ & $1.5 \pm 1.1$ \\
\hline 31 & $1.9 \pm 0.1$ & $1.4 \pm 0.6$ & $3.4 \pm 3.7$ \\
\hline
\end{tabular}

Note: $\left({ }^{*}\right)=$ not determined.

\section{Conclusions}

Through this work we have concluded that, although the Brazilian starch market is still limited when compared to those of the developed countries, there is a growing interest of the food industry in applying new ingredients of low cost and high performance. As the main starch producers are foreign companies, mainly from the United States, it is evident that corn starch predominates as the raw material for chemical modifications, especially the waxy corn starch. As shown in the presented data, cassava modified starches presented some properties related to their native counterpart, but differences could be noted in some cases, such as cooking stability, tendency to retrogradation, lower paste clarity and short rheology. The samples of sour cassava starches had the well described typical properties such as high acidity, lower viscosity peaks, higher cooking instability, higher solubility and higher paste clarity when compared to the native cassava starch. In the same manner of the native starch, the samples of sour cassava starch and those modified for the production of cheese bread presented long rheology. The most demanded types of cassava starches by the Brazilian food industry, as shown in Table 1 and all the other results, are those that resist to processing conditions as well as to low temperature storage without syneresis and retrogradation, and present smooth and short rheology, with bland flavor, acting mainly as multipurpose thickeners.

\section{Acknowledgements}

The authors are grateful to the Brazilian "Conselho Nacional de Desenvolvimento Científico e Tecnológico (CNPq)" for the financial support (Process 477458/2004-1, Edital Universal 19/2004) as well as to the scholarships (PIBIC/CNPq). The authors are also grateful to the "Financiadora de Estudos e Projetos (FINEP)" and to the "Fundação Araucária de Apoio ao Desenvolvimento Científico e Tecnológico do Paraná" for financial support (Convênio FINEP 01.05.0781.00).

\section{References}

APLEVICZ, K. S.; DEMIATE, I. M. Caracterização de amidos de mandioca nativos e modificados e utilização em produtos panificados. Ciência e Tecnologia de Alimentos, v. 27, n. 3, p. 478-484, 2007. http://dx.doi.org/10.1590/S0101-20612007000300009

BHAT, R.; KARIM, A. A. Impact of radiation processing on starch. Comprehensive Reviews in Food Science and Food Safety, v. 8, p. 44-58, 2009. http://dx.doi.org/10.1111/j.1541-4337.2008.00066.x

BEMILLER, J. N. Starch modification: challenges and prospects. Starch/Stärke, v. 49, n. 4, p. 127-31, 1997. http://dx.doi.org/10.1002/star.19970490402

BEMILLER, J. N. One Hundred Years of Commercial Food Carbohydrates in the United States. Journal of Agricultural and Food Chemistry, v. 57, p. 8125-8129, 2009. PMid:19719134. http://dx.doi.org/10.1021/jf8039236

BRASIL. Ministério da Saúde. Resolução n. 263 de setembro de 2005 da Comissão Nacional de Normas e Padrões para Alimentos. Aprova o regulamento técnico para produtos de cereais, amidos, farinhas e farelos. Diário Oficial da República Federativa do Brasil, Brasília, DF, 22 set. 2005. p. 368-369. Disponível em: <http://e-legis.anvisa. gov.br/leisref/public/showAct.php?id=18822\&word=>. Acesso em: 17 fev. 2006.

CAMARGO, C. et al. Functional properties of sour cassava (Manihot utilissima) starch: polvilho azedo. Journal of the Science of Food and Agriculture, v. 45, n. 3, p. 273-289, 1998. http://dx.doi.org/10.1002/jsfa.2740450311

CÁRDENAS, O. S.; BUCKLE, T. S. Sour cassava starch production: A preliminary study. Journal of Food Science, v. 45, n. 6, p. 1509-1512/28, 1980.

CEREDA, M. P. Padronização de qualidade de fécula de mandioca fermentada (polvilho azedo). I. Formulação e preparo de biscoitos. Boletim da SBCTA, v. 17, n. 3, p. 287-295, 1983a.

CEREDA, M. P. Determinação de viscosidade de fécula fermentada de mandioca (polvilho azedo). Boletim da SBCTA, v. 17, n. 1, p. 15-24, 1983b.

CEREDA, M. P. (Coord. ) Propriedades Gerais do Amido. São Paulo: Fundação Cargill, 2001. 221 p. (Série Culturas de Tuberosas Amiláceas Latinoamericanas, n. 1).

CEREDA, M. P.; LIMA, U. A. Aspectos sobre a fermentação da fécula de mandioca. III. Determinação dos ácidos orgânicos. Turrialba, v. 35 , n. 1, p. 19-24, 1985. 
CeredA, M. P.; VilpouX, O. F.; Demiate, I. M. Amidos modificados. In: CEREDA, M. P.; VILPOUX, O. F. Tecnologia, Usos e Potencialidades de Tuberosas Latino Americanas. São Paulo: Fundação Cargill, 2003. p. 246-332. (Série Culturas de Tuberosas Amiláceas Latino Americanas, v. 3).

CEREDA, M. P.; WOSIACKI, G. Characterization of pinhão starch. Part II. Rheological properties of the pastes. Starch/Stärke, v. 37, n. 12, p. 404-407, 1985. http://dx.doi.org/10.1002/star.19850371203

CHE, L. M. et al. Micronization and hydrophobic modification of cassava starch. International Journal of Food Properties, v. 10, p. 527-536, 2007. http://dx.doi.org/10.1080/10942910600932982

CRAIG, S. A. S. et al. Starch Paste Clarity. Cereal Chemistry, v. 66, n. 3, p. 173-182, 1989.

DEMIATE. I. M. et al. Organic acid profile of commercial sour cassava starch. Ciência e Tecnologia de Alimentos, v. 19, n. 1, p. 131-135, 1999.

DEMIATE, I. M. et al. Relationship between baking behavior of modified cassava starches and starch chemical structure determined by FTIR spectroscopy. Carbohydrate Polymers, v. 42, n. 2, p. 149-158, 2000. http://dx.doi.org/10.1016/S0144-8617(99)00152-6

INSTITUTO ADOLFO LUTZ - IAL. Normas analíticas do Instituto Adolfo Lutz. Métodos químicos e físicos para análise de alimentos. 3. ed. São Paulo: IAL, 1985. v. 1, 533 p.

KITE, E. E.; MAYWALD, E. C.; SCHOCH, T. J. Funktionelle Eigenschaften von Lebensmittelstärken. Starch/Stärke, v. 15, n. 4, p. 131-138, 1963. http://dx.doi.org/10.1002/star.19630150405

LEACH, H. W.; McCOWEN, L. D.; SCHOCH, T. J. Structure of the starch granule. I. Swelling and solubility patterns of various starches. Cereal Chemistry, v. 36, n. 6, p. 534-544, 1959.

MARCON, M. J. A.; AVANCINI, S. R. P.; AMANTE, E. R. Propriedades químicas do amido de mandioca e do polvilho azedo. Florianópolis: Editora da UFSC, 2007. 101 p.

MARCON, M. J. A. et al. Effect of the Improved Fermentation on Physicochemical Properties and Sensorial Acceptability of Sour Cassava Starch. Brazilian Archives of Biology and Technology, v. 50, n. 6, p. 1073-1081, 2007. http://dx.doi.org/10.1590/S151689132007000700018

MESTRES, C.; ROUAU, X. Influence of natural fermentacion and drying conditions on the physicochemical characteristics of cassava starch. Journal of the Science of Food and Agriculture, v. 74, n. 2, p. 147-155, 1997. http://dx.doi.org/10.1002/(SICI)10970010(199706)74:2\%3C147::AID-JSFA781\%3E3.0.CO;2-J
NAKAMURA, I. M.; PARK. Y. K. Some physicochemical properties of fermented cassava starch (polvilho azedo). Die Stärke, v. 27, n. 9, p. 295-297, 1975.

PETRUCELLI, S. et al. Characterization of fermented cassava starches. Journal of Food Biochemistry, v. 17, n. 3, p. 161-172, 1993. http://dx.doi.org/10.1111/j.1745-4514.1993.tb00465.x

PLATA-OVIEDO, M.; CAMARGO, C. Effect of acid treatments and drying processes on physico-chemical and functional properties of cassava starch. Journal of the Science of Food and Agriculture, v. 77, n. 1, p. 103-108, 1998. http://dx.doi.org/10.1002/(SICI)10970010(199805)77:1\%3C103::AID-JSFA10\%3E3.0.CO;2-2

SCHMITZ, C. S. et al. Cassava starch functional properties by etherification - hydroxypropylation. International Journal of food Science and Technology, v. 41, p. 681-687, 2006. http://dx.doi.org/10.1111/j.1365-2621.2005.01136.x

SHARP, R. N.; SHARP, C. Q. Food applications for modified rice starches. In: MARSHALL, W. E.; WADSWORTH, J. I. Rice Science and Technology. New York: Marcel Dekker, 1994. p. 405-420.

SHI, X.; BEMILLER, J. N. Effects of food gums on viscosities of starch suspensions during pasting. Carbohydrate Polymers, v. 50, n. 1, p. 7-18, 2002. http://dx.doi.org/10.1016/S0144-8617(01)00369-1

SILVA, G. O. et al. Características físico-químicas de amidos modificados de grau alimentício comercializados no Brasil. Ciência e Tecnologia de Alimentos, v. 26, n. 1, p. 188-197, 2006. http://dx.doi.org/10.1590/S0101-20612006000100030

SMITH, R. J. Characterization and analysis of starches. In: WHISTLER, R. L.; PASCHALL. E. F. Starch: Chemistry and Technology. New York: Academic Press, 1967. v. 2, p. 569-635.

SWINKELS, J. J. M. Industrial starch chemistry: properties, modifications and applications of starches. Veendam: AVEBE, 1996. $48 \mathrm{p}$.

TAKIZAWA, F. F. et al. Characterization of tropical starches modified with potassium permanganate and lactic acid. Brazilian Archives of Biology and Technology, v. 47, n. 6, p. 921-931, 2004. http://dx.doi.org/10.1590/S1516-89132004000600012

WETSBY, A.; CEREDA, M. P. Production of fermented cassava starch (polvilho azedo) in Brazil. Tropical Science, v. 34, n. 2, p. 203-210, 1994.

WURZBURG, O. B. Modified starches: properties and uses. Boca Raton: CRC Press, 1986. 277 p. 